УДК 556.11

DOI 10.18101/2306-2363-2019-4-3-8

\title{
МОНИТОРИНГ ФИЗИКО-ХИМИЧЕСКИХ ПОКАЗАТЕЛЕЙ ВОДЫ ОЗЕРА ГУСИНОЕ
}

\section{(C) О. П. Дагурова}

кандидат биологических наук, старший научный сотрудник, Институт общей и экспериментальной биологии СО РАН 670047, Улан-Удэ, ул. Сахьяновой, 6

E-mail: dagur-ol@mail.ru

\section{(C) С. В. Зайцева}

кандидат биологических наук, научный сотрудник, Институт общей и экспериментальной биологии СО РАН 670047, Улан-Удэ, ул. Сахьяновой, 6

E-mail: svet_zait@mail.ru

\section{(C) Б. В. Цыденова}

аспирант,

Институт общей и экспериментальной биологии СО РАН 670047, Улан-Удэ, ул. Сахьяновой, 6

E-mail: bayarma73@mail.ru

\section{(C) В. Б. Дамбаев}

кандидат биологических наук, научный сотрудник, Институт общей и экспериментальной биологии СО РАН 670047, Улан-Удэ, ул. Сахьяновой, 6

E-mail: slavadmb@mail.ru

\section{(C) Д. В. Матафонов}

кандидат биологических наук, заместитель директора по науке, Байкальский филиал ФГБНУ «ВНИРО»

670034, Улан-Удэ, ул. Хахалова, 4б

E-mail:dimataf@yandex.ru

Оценены значения физико-химические показателей на различных участках акватории озера Гусиное. Выявлено, что температура, $\mathrm{pH}$ и окислительно-восстановительные условия среды, в большей степени определяли распределение образцов в пространстве главных компонент. По результатам кластеризации образцов выявлены участки озера со сходными экологическими параметрами и обнаружены участки с отличающимися от обычных, условиями, что позволяет отнести их к экологическим нишам с потенциальным развитием нехарактерных для озера групп гидробионтов.

Ключевые слова: озеро Гусиное, физико-химические показатели; температура; мониторинг; гидробионты; экологические параметры; биогенные вещества.

Для цитирования: Дагурова О. П., Зайцева С. В., Цыленова Б. В., Дамбаев В. Б., Матафонов Д. В. Мониторинг физико-химических показателей воды озера Гусиное // Вестник Бурятского государственного университета. Химия. Физика. 2019. Вып 4. С. 3-8. 
Изучение пресных озер имеет большое значение для понимания воздействия природных факторов и человеческой деятельности на экосистемные структуры и функции. Мониторинг химического состава вод, продукционно-деструкционных, гидробиологических характеристик важен для оценки трофического статуса водоемов и определения качества воды.

Озеро Гусиное - крупнейший пресноводный водоем Республики Бурятия, который расположен на территории Селенгинского среднегорья. Площадь озера составляет 164 км², водосборная площадь бассейна равна 924 км². Озеро относится к малопроточным водоемам с замедленным водообменом. В озеро впадает 9 рек, и вытекает одна - Баин-Гол [1]. Озеро Гусиное используется для хозяйственнопитьевого водоснабжения. Сохранение крупного источника питьевой воды является важнейшей экологической проблемой. Озеро Гусиное также имеет рыбохозяйственное и рекреационное значение. Озеро подвержено значительному антропогенному воздействию и используется как естественный водоем-охладитель Гусиноозерской ГРЭС, подвергается значительному антропогенному воздействию со стороны ГРЭС и населенных пунктов вокруг него (теплые воды, поступающие после охлаждения агрегатов ГРЭС, атмосферные выбросы ГРЭС, коммунальнобытовые сточные воды города Гусиноозерска и села Гусиное озеро).

На современном этапе изучается гидрохимическое состояние озера Гусиное как источника питьевой воды и объекта антропогенного воздействия [2-5]. Кроме того, актуальным является мониторинг экологического состояния озера как места обитания различных гидробионтов.

Цель работы - оценить физико-химические показатели озера Гусиное и провести кластеризацию образцов по этим показателям.

\section{Объекты и методы}

Образцы воды в озере Гусиное отбирались на 11 станциях, подверженных антропогенному прессу, из которых 6 станций находятся в зоне теплового влияния в северной части озера, 2 станции в центральной части озера (одна из них в каче-

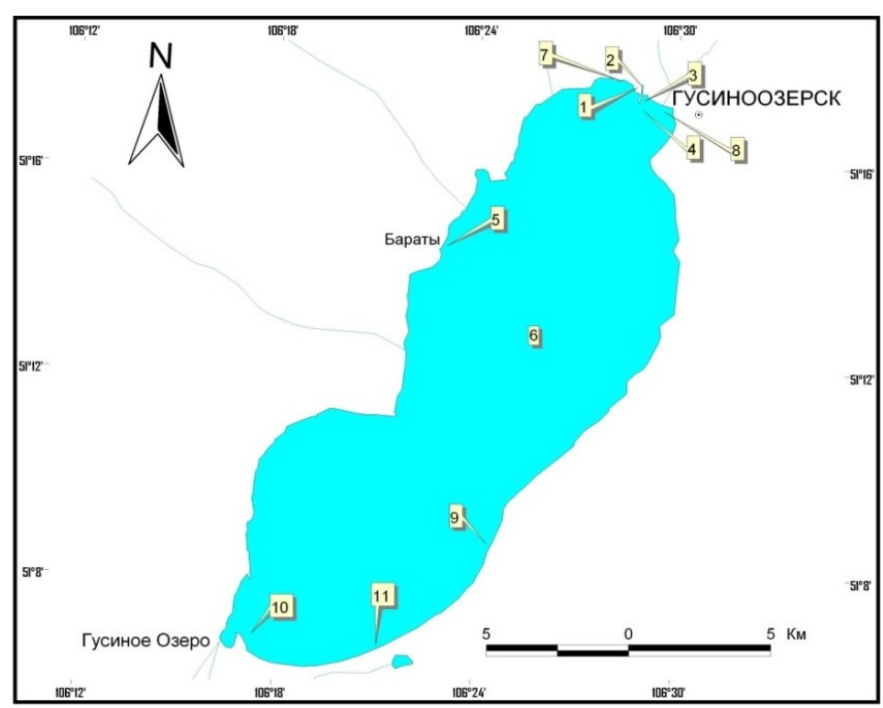
стве контроля) и 3 станции - в южной части озера (рис. 1).

Рис. 1. Озеро Гусиное: расположение станций отбора образцов: 1 - водозабор, 2 - сброс теплых вод, 3 - сбросной канал, $4-$ вход в озеро, 5 - около ж/д станции Бараты, 6 - центр озера (контроль), 7 - устье реки Тэли, 8 - устье реки Загустай, 9- Хальбоджинский угольный разрез, 10 устье реки Цаган-Гол, 11 исток реки Баин-Гол. 
О. П. Дагурова, С. В. Зайцева, Б. В. Цыденова, В. Б. Дамбаев, Д. В. Матафонов. Мониторинг физико-химических показателей воды озера Гусиное

Температуру и величину рН измеряли портативным прибором «РН-200» (НM Digital, Китай), окислительно-восстановительный потенциал (Eh) - прибором «ORP-169B» (Kelilong, Китай). Содержание растворенного кислорода определяли по методу Винклера [6]. Концентрации анионов и катионов, общая щелочность, величина сухого остатка были определены методами, общепринятыми в гидрохимии водоемов.

\section{Результаты и обсуждение}

Значения физико-химических показателей в большинстве показателей мало различались по акватории озера, за исключением повышения температуры в сбросном канале теплых вод и отсутствия кислорода в точке 10 в 2018 г. (табл. 1).

Таблица 1

Физико-химические показатели воды озера Гусиное в 2015-2018 гг.

\begin{tabular}{|c|c|c|c|c|c|}
\hline Станция & $\mathrm{T},{ }^{\circ} \mathrm{C}$ & $\mathrm{pH}$ & Eh, $M B$ & $\begin{array}{c}\text { Минерализация, } \\
\text { мг/дм }\end{array}$ & $\mathrm{O}_{2}, \mathrm{Mr} / \mathrm{дm}^{3}$ \\
\hline Гус 1 & $\frac{6,2-18,2}{10,2 \pm 5,6}$ & $\frac{7,5-8,8}{8,2 \pm 0,5}$ & $\frac{107-188}{178 \pm 67}$ & $\frac{216-408}{298 \pm 86}$ & $\frac{4,8-17,9}{10,7 \pm 5,0}$ \\
\hline Гус2 & $\frac{11,2-23,1}{16,7 \pm 5,2}$ & $\frac{8,2-8,8}{8,6 \pm 0,2}$ & $\frac{156-242}{184 \pm 49}$ & $\frac{219-403}{272 \pm 88}$ & $\frac{8,9-12,2}{9,7 \pm 1,6}$ \\
\hline Гус 3 & $\frac{10,4-24,8}{16,4 \pm 6,4}$ & $\frac{8,1-9,0}{8,4 \pm 0,5}$ & $\frac{69-219}{144 \pm 106}$ & $\frac{221-404}{289 \pm 100}$ & $\frac{7,4-10,2}{8,4 \pm 1,5}$ \\
\hline Гус4 & $\frac{5,1-24,8}{12,7 \pm 10,6}$ & $\frac{8,4-8,8}{8,6 \pm 0,2}$ & $\frac{131-198}{166 \pm 33}$ & $\frac{223-413}{277 \pm 90}$ & $\frac{8,4-10,5}{9,5 \pm 1,0}$ \\
\hline Гус 5 & $\frac{0,1-22,0}{10,7 \pm 11,2}$ & $\frac{8,1-8,6}{8,4 \pm 0,2}$ & $\frac{167-173}{169 \pm 3}$ & $\frac{222-422}{284 \pm 92}$ & $\frac{8-13,4}{10,3 \pm 2,7}$ \\
\hline Гус 6 & $\frac{0,1-24,1}{7,5 \pm 11,2}$ & $\frac{8,1-8,6}{8,4 \pm 0,1}$ & $\frac{135-205}{176 \pm 36}$ & $\frac{133-425}{255 \pm 112}$ & $\frac{7,68-12,8}{10,3 \pm 2,0}$ \\
\hline Гус 7 & $\frac{5,1-25,2}{12,0 \pm 9,8}$ & $\frac{8,3-8,8}{8,5 \pm 0,2}$ & $\frac{165-227}{183 \pm 33}$ & $\frac{221-410}{278 \pm 88}$ & $\frac{8,6-10,8}{9,4 \pm 1,2}$ \\
\hline Гус 8 & $\frac{7,7-25,6}{14,6 \pm 9,6}$ & $\frac{8,5-9,1}{8,8 \pm 0,2}$ & $\frac{131-209}{166 \pm 39}$ & $\frac{228-413}{282 \pm 87}$ & $\frac{8,9-13,6}{11,3 \pm 2,3}$ \\
\hline Гус 9 & $\frac{2,0-22,7}{12,4 \pm 14,6}$ & $\frac{8,5-8,7}{8,6 \pm 0,1}$ & $\frac{124-173}{155 \pm 27}$ & $\frac{223-433}{328 \pm 148}$ & $\frac{11,0-16,0}{13,2 \pm 2,3}$ \\
\hline Гус 10 & $\frac{0,1-23,8}{7,8 \pm 10,9}$ & $\frac{7,2-8,7}{8,1 \pm 0,7}$ & $\frac{-139-191}{78 \pm 187}$ & $\frac{152-416}{266 \pm 134}$ & $\frac{0-10,8}{7,1 \pm 5,0}$ \\
\hline Гус 11 & $\frac{0,1-23,6}{9,1 \pm 9,9}$ & $\frac{7,6-8,7}{8,2 \pm 0,5}$ & $\frac{70-170}{120 \pm 70}$ & $\frac{39-449}{249 \pm 205}$ & $\frac{12,6-14,7}{13,6 \pm 1,4}$ \\
\hline
\end{tabular}

В числителе - наименьшее и наибольшее значение, в знаменателе - среднее значение. Жирным шрифтом выделены значения, отличающиеся от таковых в других станциях.

Температура в месте сброса теплых вод и незамерзающем сбросном канале в марте, во время ледового режима значительно превышала температуру вод в озере. К выходу из сбросного канала в озеро температура незначительно снижалась. 
Воды озера были слабощелочные (pH 7,2-9,1), с максимумом в точке сброса теплых вод и в устье р. Загустай. Общая минерализация в среднем составляла 280 мг/дм³ ${ }^{3}$ В марте 2017 г. было зафиксировано повышение минерализации - до 449 мг/дм³. Это повышение согласуется с определенными в 2016 г. значениями [5] и демонстрируют увеличение количества содержащихся в воде растворённых веществ (с 233 до 400 мг/дм ${ }^{3}$ ) с соответствующим увеличением содержания ионов в макрокомпонентном составе, в особенности сульфат-ионов и щелочных металлов, по сравнению с исследованиями, проведенными до строительства Гусиноозерской ГРЭС и начала промышленной разработки Хальбоджинского угольного разреза [1]. Увеличение концентраций сульфата, натрия, биогенных и органических веществ на участках, подверженных техногенному воздействию, отмечено также в работе [4]. Содержание растворенного кислорода было высоким (до 17,9 мг/дм³), значения Eh до 242 мВ. На станции Гус 10, в устье р. ЦаганГол, в марте 2018 г. была отобрана проба, резко отличающаяся от остальных восстановленными условиями (Eh $=-139 \mathrm{MB})$, отсутствием растворенного кислорода. По органолептическим показателям проба также отличалась - вода была окрашена, с резким запахом сероводорода.

Была проведена кластеризация исследуемых образцов на основе измеренных физико-химических параметров (рис. 2).

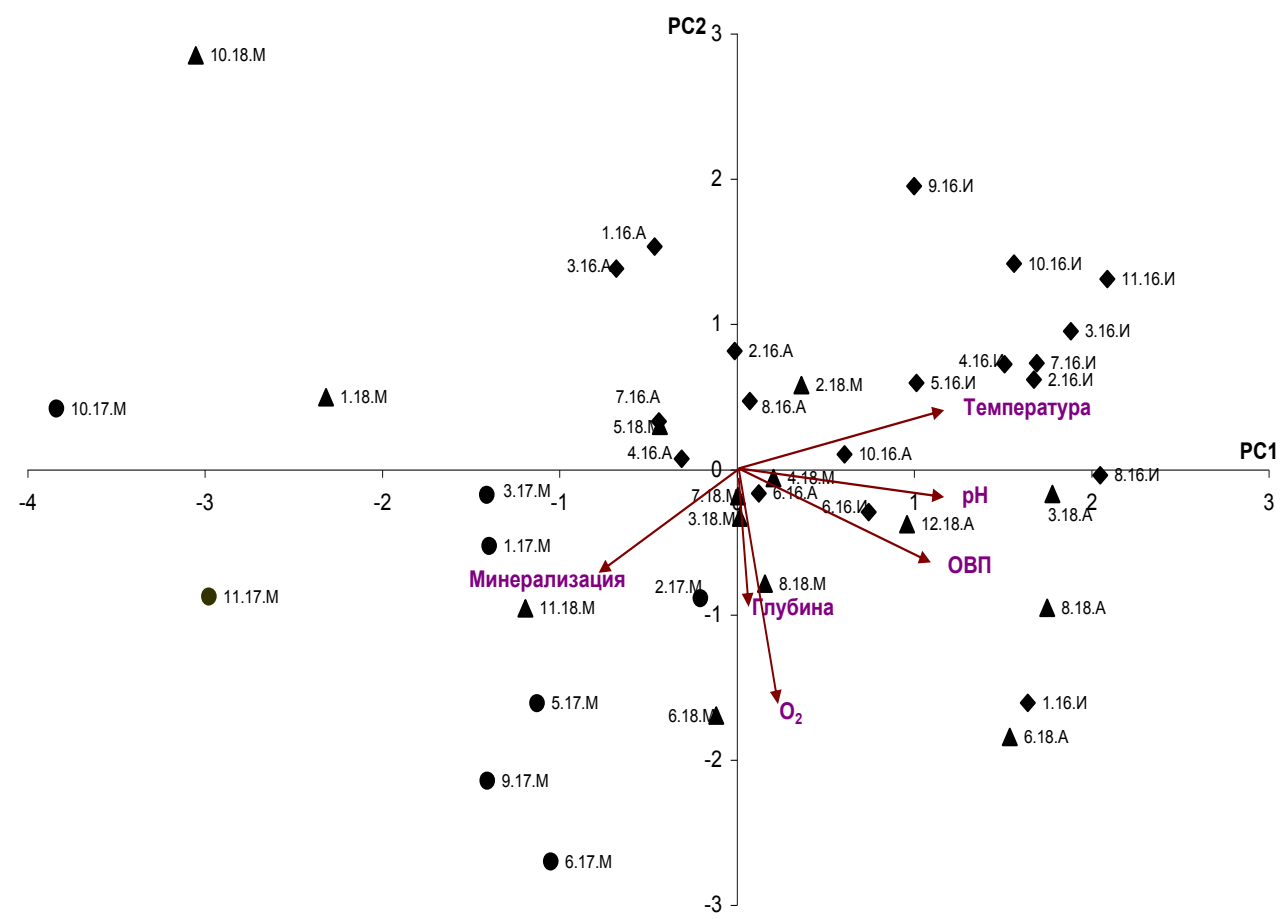

Рис. 2. Распределение образцов в зависимости от физико-химических показателей

Выявлено, что температура, $\mathrm{pH}$ и окислительно-восстановительные условия среды, в большей степени, определяли распределение образцов в пространстве главных компонент. Так, июньские пробы 2016 г., значения показателей которых 
О. П. Дагурова, С. В. Зайцева, Б. В. Цыденова, В. Б. Дамбаев, Д. В. Матафонов. Мониторинг физико-химических показателей воды озера Гусиное

находятся в правой верхней части графика, характеризовались повышенными температурами и более щелочными значениями рН. Высокие значения рН могут быть обусловлены действием цианобактериального пула, который активно развивается именно в летний период [7]. Крайне обособленное положение пробы из устья р. Цаган-Гол (левая верхняя часть графика, точка 10.18.M) связано с восстановленными условиями среды и отсутствием растворенного кислорода.

По типу вода озера определена как сульфатно-гидрокарбонатно-натриевая. Максимальная концентрация гидрокарбонатов составляла 235 мг/дм³, натрия 69 мг/дм ${ }^{3}$, кальция - 33 мг/дм³ ${ }^{3}$ магния - 25 мг/дм³ ${ }^{3}$ Обнаружено высокое содержание сульфатов - до 77 мг/дм³ . Максимальное количество сухого остатка, характеризующего общее содержание органических и минеральных соединений, составляло 332 мг/дм³ ${ }^{3}$ По этому показателю (допустимый максимум 1000 мг/дм $\left.{ }^{3}\right)$, воду озера можно охарактеризовать как «пригодную для хозяйственнопитьевых целей». По показателю общей жесткости вода озера относится к «мягкой», согласно СанПиН 2.1.4.1074-01. По показателям жесткости и сухого остатка вода была пригодна для питьевых целей.

В устье реки Цаган-Гол в 2018 г. обнаружен локальный экотоп, резко отличавшийся по физико-химическим характеристикам от других станций. Вода характеризовалась отсутствием кислорода, повышением минерализации, обогащением сульфатами и хлоридами осадка в этой точке, что, возможно, свидетельствует о проявлениях вулканической деятельности на дне озера Гусиное [8].

Таким образом, оценены значения физико-химические показателей в различных участках акватории озера Гусиное. Наиболее изменяемыми показателями были температура, $\mathrm{pH}$ и окислительно-восстановительный потенциал. По результатам кластеризации образцов были выявлены участки озера со сходными экологическими параметрами и обнаружены участки с отличающимися от обычных условиями, что позволяет отнести их к экологическим нишам с потенциальным развитием нехарактерных для озера групп гидробионтов.

Работа выполнена в рамках реализаџии базового проекта ФАНО «Микробные сообщества экстремальных природных систем: биологическое и функциональное разнообразие, биотехнологический потенщиал» № AAAA-A17-117011810034-9 и при поддержке гранта РФФИ № 18-44-030028.

\section{Литература}

1. Борисенко И. М., Пронин Н. М., Шайбонов Б. Б. и др. Экология озера Гусиное. — Улан-Удэ: Изд-во БНЦ СО РАН, 1994. — 196 с.

2. Хахинов В. В., Намсараев Б. Б., Бархутова Д. Д. и др. Гидрохимические и микробиологические характеристики Гусино-Убукунских водоемов // Водные ресурсы. 2005. - Т. 32, № 1. - С. 79-84.

3. Абидуева Е. Ю., Дагурова О. П., Гаранкина В. П., Самбуева Г. Б. Сезонные изменения физико-химических и микробиологических показателей озера Гусиное // Вестник Бурятского госуниверситета. Химия Физика. - 2014. — № 3. - С. 74-76.

4. Хажеева 3. И., Плюснин А. М. Современное состояние воды озера Гусиное (Западное Забайкалье) // Водные ресурсы. - 2018. — Т. 45, №1. - С. 68-74.

5. Цыдыпов Б. 3., Андреев С. Г., Аюржанаев А. А. и др. Влияние сбросов Гусиноозерской ГРЭС на термический и гидрохимический режим озера Гусиное // Изв. Иркутского госуниверситета. Серия «Науки о Земле». - 2017. — № 22. — С. 135-150. 
6. Романенко В. И., Кузнецов С. И. Экология микроорганизмов пресных водоемов Лабораторное руководство. - Л.: Наука, 1974. — 194 с.

7. Tsydenova B. V., Dagurova O. P., Garankina V. P. and al. Abundance and taxonomic composition of bacterioplankton in freshwater Lake Gusinoye (Buryatia) in the warm water zone of the Gusinoozerskaya thermal power plant // J. Sib. Fed. Univ. Biol. — 2018. — V. 11, № 4. - P. 356-366.

8. Татаринов А. В., Яловик Л. И., Канакин С. В. Особенности формирования и минеральные ассоциации литокомплексов грязевых вулканов на юге Восточной Сибири // Вулканология и сейсмология. - 2016. - № 4. - С. 34-49.

\section{MONITORING OF PHYSICAL AND CHEMICAL PARAMETERS THE WATER OF LAKE GUSINOE}

Dagurova $O$. $P$.

Candidate of Biology Sciences

Institute of General and Experimental Biology SB RAS

670047, Ulan-Ude, Sakhyanovoy Str., 6

E-mail: dagur-ol@mail.ru

Zaitseva S. $V$.

Candidate of Biology Sciences

Institute of General and Experimental Biology SB RAS

670047, Ulan-Ude, Sakhyanovoy Str., 6

E-mail: svet_zait@mail.ru

Tsydenova B. $V$

Postgraduate

Institute of General and Experimental Biology SB RAS

670047, Ulan-Ude, Sakhyanovoy Str., 6

E-mail: bayarma73@mail.ru

Dambaev V. B.

Candidate of Biology Sciences

Institute of General and Experimental Biology SB RAS

670047, Ulan-Ude, Sakhyanovoy Str., 6

E-mail: slavadmb@mail.ru

Matafonov D. V.

Candidate of Biology Sciences

Baikal Branch of VNIRO "BaikalNIRO"

670034, Ulan-Ude, Khakhalova Str., 4B

E-mail:dimataf@yandex.ru

The values of physico-chemical parameters in various parts of the water area of Lake Gusinoe are estimated. It was revealed that the temperature, $\mathrm{pH}$, and redox conditions of the environment to a greater extent determined the distribution of samples in the space of the main components. Based on the results of the clustering of the samples, the sites of the lake with similar environmental parameters were identified and sites with conditions differ from usual were found. In these sites are the ecological niches with potential development of uncharacteristic hydrobionts groups.

Keywords: Lake Gusinoe, physico-chemical parameters; temperature; monitoring; hydrobionts; ecological parameters; biogenic substances. 